Check for updates

Cite this: RSC Adv., 2018, 8, 8450

Received 25th January 2018

Accepted 3rd February 2018

DOI: $10.1039 / \mathrm{c} 8 \mathrm{ra00524a}$

rsc.li/rsc-advances

\section{Iridium-catalysed direct sulfamidation of quinazolinones $\uparrow$}

\author{
Yadong Feng, Yudong Li, Yunliang Yu, Lianhui Wang and Xiuling Cui (iD) * \\ Ir-catalysed direct sulfamidation of quinazolinones has been achieved. A series of ortho-diamided \\ quinazolinones were obtained in up to $96 \%$ yields. This transformation could proceed smoothly with \\ a low catalyst loading under mild conditions with nitrogen released as the sole byproduct. This approach \\ potentially provides an environmentally benign sulfamidation process for atom/step economic syntheses \\ of useful pharmaceutical molecules or important building blocks.
}

Over the past two decades, $\mathrm{C}-\mathrm{H}$ bond functionalization has attracted considerable attention for its outstanding advantages in atom efficiency and synthesis step efficiency compared to the traditional cross-coupling reactions. ${ }^{1}$ Prefunctionalization and multiple tedious purification steps can be avoided while enhancing the step economy of the transformation and decreasing the byproduct formation in these processes. ${ }^{2}$ Therefore, direct functionalization of $\mathrm{C}-\mathrm{H}$ bond has become an increasingly attractive strategy for the synthesis and derivatization of natural products and pharmaceutically relevant building blocks. ${ }^{3}$ However, controlling site selectivity is one of the challenges in $\mathrm{C}-\mathrm{H}$ bond activation. In this regard, the strategy involving regioselective $\mathrm{C}-\mathrm{H}$ bond activation assisted by directing group shows high potential. So far, various directing groups containing oxygen or nitrogen atoms have been developed successfully. As is well-known, quinazolinones are a significant class of compounds because of their pharmaceutical applications and biological activities. In particular, quinazolinones have been found to be with various bioactivities, such as antibacterial, ${ }^{4}$ antifungal, ${ }^{5}$ antimalarial, ${ }^{6}$ anticancer, ${ }^{7}$ antihypertensive, ${ }^{8}$ antitubercular, ${ }^{9}$ and anticonvulsant. ${ }^{10}$ Forward this direction, our group has developed a series of easy methods in modification of quinazolinones via metal-catalysed $\mathrm{C}-\mathrm{H}$ bond functionalization, in which quinazolinones act as directing groups since there are two $\mathrm{N}$ atoms in these structures. ${ }^{11}$ In addition, organic azide, as an internal oxidant and environmentally benign reagent, has been extensively explored in amidation reactions because nontoxic nitrogen gas is released as the only byproduct. ${ }^{12}$ Recently, our group has developed an Ir-catalysed amidation of benzaldehydes with

Engineering Research Center of Molecular Medicine of Ministry of Education, Key Laboratory of Fujian Molecular Medicine, Key Laboratory of Xiamen Marine and Gene Drugs, School of Biomedical Sciences, Huaqiao University, Xiamen 361021, P. R. China.E-mail: cuixl@hqu.edu.cn

$\dagger$ Electronic supplementary information (ESI) available: General information, experimental procedures, copies of ${ }^{1} \mathrm{H},{ }^{13} \mathrm{C}$ and ${ }^{19} \mathrm{~F}$ NMR spectra for products. See DOI: $10.1039 / \mathrm{c} 8 \mathrm{ra00524a}$ sulfonyl azides as amino sources. ${ }^{13}$ In our continuing effort to develop green methods in $\mathrm{C}-\mathrm{H}$ bond activation, ${ }^{14}$ herein, we disclose an Ir-catalysed direct amidation of 2-arylquinazolinones with sulfonyl azides as amino sources to produce orthodiamided quinazolinones (Scheme 1), in which symmetrical diamidated products was selectively obtained with high yields by controlling the amount of azide. This procedure could proceeded smoothly with a low catalyst loading and tolerate various substituent groups with $\mathrm{N}_{2}$ as the sole byproduct. The titled products are an important building block in organic synthesis and can be potentially converted into various highly valuable molecules via diverse transformations.

Initially, the amidation of 2-phenylquinazolin-4-(3H)-one (1a) with para-toluenesulfonyl azide (2a) (3.0 equiv.) was chosen as a model reaction to examine the impact of various parameters on the reaction (Table 1). The results revealed that $N, N^{\prime}-(2-$ (4-oxo-3,4-dihydroquinazolin-2-yl)-1,3-phenylene)bis(4-methyl benzenesulfonamide) (3a) was obtained as a main product in $96 \%$ yield in DCE at $80{ }^{\circ} \mathrm{C}$ when $\left[\mathrm{IrCp}^{*} \mathrm{Cl}_{2}\right]_{2}(1 \mathrm{~mol} \%)$ was used as a catalyst with $\mathrm{AgSbF}_{6}$ (4 mol\%), $\mathrm{CF}_{3} \mathrm{COOH}$ (4 equiv.) under air (Table 1, entry 1). We tried the first set of conditions displayed in entry 1 of Table 1 firstly, and found they are the optimum reaction conditions fortunately. When the loading amount of $2 \mathrm{a}$ was reduced to 2.0 or 1.0 equivalent, the reaction was complex and gave the mixture of the mono- (4a, Scheme $2 \mathrm{a}$ ) and di-amidated products (3a). Only $75 \%$ and $60 \%$ yield of the target product 3a was achieved when the reaction was carried out under $\mathrm{O}_{2}$ and $\mathrm{N}_{2}$ protection (Table 1, entries 2-3). Other metal salts, such as $\mathrm{Pd}(\mathrm{OAc})_{2}$ and $\left[\mathrm{RhCp}^{*} \mathrm{Cl}_{2}\right]_{2}$ were screened,

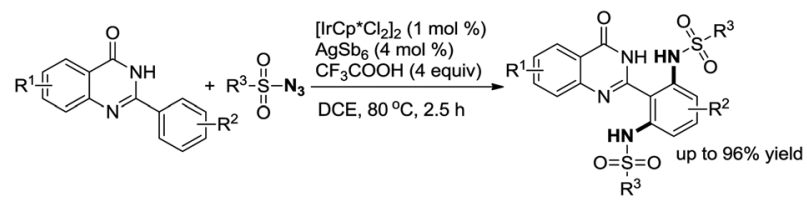

Scheme 1 Ir-catalysed direct amidation of 2-arylquinazolinones. 
Table 1 Optimization of the reaction conditions ${ }^{a}$

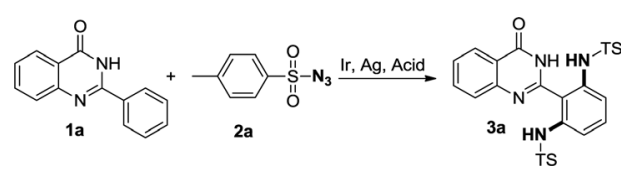

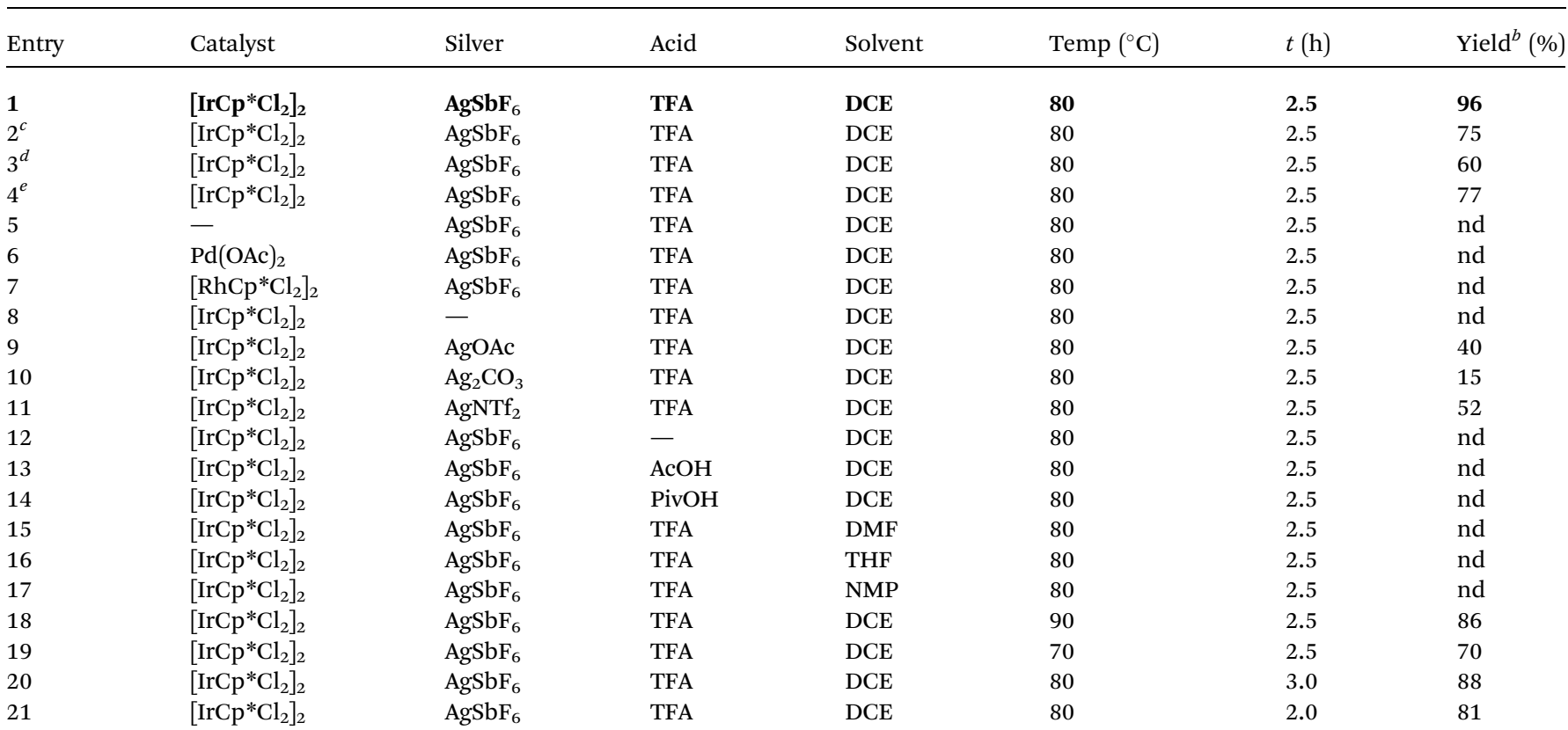

${ }^{a}$ Reaction conditions: 1a $(0.20 \mathrm{mmol}), 2 \mathrm{a}(0.60 \mathrm{mmol}), \mathrm{Ir}(1 \mathrm{~mol} \%), \mathrm{Ag}(4 \mathrm{~mol} \%)$, acid (4.0 equiv.), solvent $(2 \mathrm{~mL}) .{ }^{b}$ Isolated yields. ${ }^{c} \mathrm{O}_{2} \cdot{ }^{d} \mathrm{~N}_{2} \cdot{ }^{e} \mathrm{Ir}$ (0.5 mol\%), Ag ( $2 \mathrm{~mol} \%)$. nd = not detected.

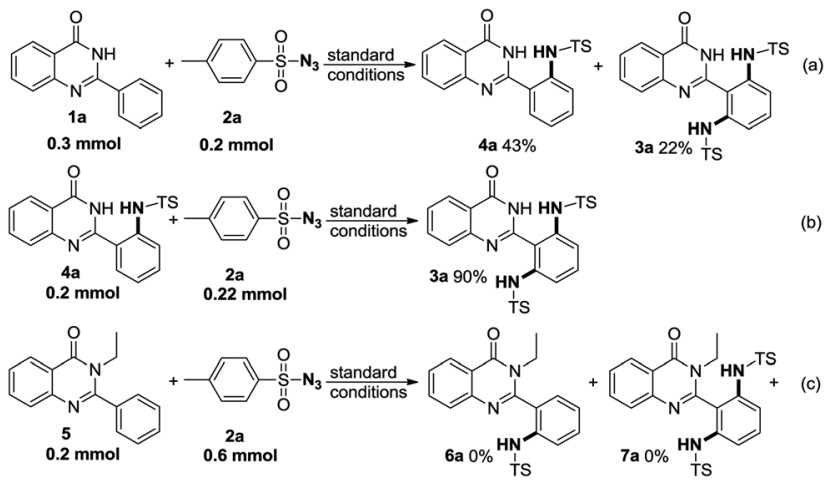

Scheme 2 Exploration of the reaction mechanism.

showing that the reaction did not proceed without Ir catalyst and the yield of $\mathbf{3 a}$ was decreased when the loading of catalyst was reduced to $0.5 \mathrm{~mol} \%$ (Table 1, entry $1 \mathrm{vs}$. entries 4-7). Moreover, $\mathrm{AgSbF}_{6}$ was shown to favor this reaction than other $\mathrm{Ag}$ salts (Table 1 , entry 1 vs. entries 8-11). TFA was chosen to be better acid (Table 1 , entry 1 vs. entries 12-14). On the other hand, DCE was demonstrated to be the best solvent (Table 1, entry $1 v s$. entries 15-17). The yield of $3 a$ decreased when the reaction temperature and reaction time were changed (Table 1, entries 18-21). Based on the results, under the optimum reaction conditions, the target product 3 a was obtained in $96 \%$ yield in DCE at $80{ }^{\circ} \mathrm{C}$ when $\left[\mathrm{IrCp}^{*} \mathrm{Cl}_{2}\right]_{2}(1 \mathrm{~mol} \%)$ was used as a catalyst with $\mathrm{AgSbF}_{6}$ (4 mol\%), $\mathrm{CF}_{3} \mathrm{COOH}$ (4 equiv.) under air (Table 1, entry 1).

With the optimized reaction conditions in hand, the scope of the substrates was examined (Table 2). First, toluenesulfonyl azide (2a) reacted smoothly with 2-phenylquinazolin-4-(3H)-one (1a) and its derivatives (1)-1l) to give 3a-3l in good to excellent yields (60-96\%). Halogen groups, such as $\mathrm{F}, \mathrm{Cl}$, and methoxyl at the 5- or 6-position of quinazolinones provided the corresponding products $3 \mathbf{b}-3 \mathbf{d}$ in $86 \%, 78 \%$ and $92 \%$ yields, respectively, which indicated that the electron density on the moiety of the quinazolinones did not significantly influence the efficiency of the reaction. F group at the meta- and para-position of 2-phenyl in 2-aryl-quinazolin-4-(3H)-one provided the corresponding products $3 \mathrm{e}-3 \mathrm{f}$ in $65 \%$ and $94 \%$ yields. Other groups, such as $\mathrm{Cl}, \mathrm{Br}$, trifluoromethyl, methyl, $t$-butyl, and methoxyl could be well tolerated and gave the corresponding products in satisfactory yields (3g-31) (60-96\%). However, no product was obtained with functional groups such as $-\mathrm{CN},-\mathrm{NO}_{2}$, and $-\mathrm{OH}$ in 2-aryl-quinazolin-4-(3H)-one. 2-Phenylquinazolin-4-(3H)-one (1a) also reacted smoothly with substituted azides (2b-2d) to give the desired products $3 \mathbf{m}-\mathbf{3 o}$ in $80-89 \%$ yields. It can be seen that the electron density on the aromatic moiety of the azides did not significantly influence the efficiency of the reaction, and alkyl azide could also be tolerated in this procedure. 
Table 2 Scope of substrates ${ }^{a, b}$

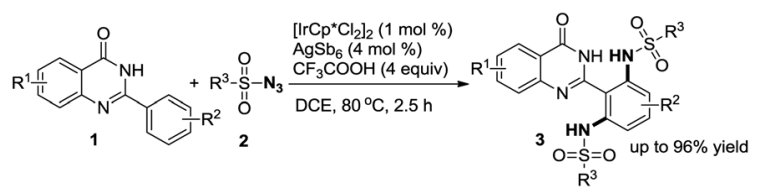

\begin{tabular}{|c|c|c|c|c|}
\hline Entry & 1 & 2 & 3 & Yield $^{b}(\%)$ \\
\hline 1 & $1 a, R^{1}=H ; R^{2}=H$ & $2 a, \mathrm{R}^{3}=4-\mathrm{CH}_{3} \mathrm{C}_{6} \mathrm{H}_{4}$ & $\mathbf{3 a}$ & 96 \\
\hline 2 & $\mathbf{1 b}, \mathrm{R}^{1}=5-\mathrm{F} ; \mathrm{R}^{2}=\mathrm{H}$ & $2 a, \mathrm{R}^{3}=4-\mathrm{CH}_{3} \mathrm{C}_{6} \mathrm{H}_{4}$ & $3 \mathbf{b}$ & 86 \\
\hline 4 & $\mathbf{1 d}, \mathrm{R}^{1}=6-\mathrm{OCH}_{3} ; \mathrm{R}^{2}=\mathrm{H}$ & $2 \mathrm{a}, \mathrm{R}^{3}=4-\mathrm{CH}_{3} \mathrm{C}_{6} \mathrm{H}_{4}$ & $3 d$ & 92 \\
\hline 5 & $1 e, R^{1}=H ; R^{2}=3-F$ & $2 a, \mathrm{R}^{3}=4-\mathrm{CH}_{3} \mathrm{C}_{6} \mathrm{H}_{4}$ & $3 e$ & 65 \\
\hline 6 & $\mathbf{1 f}, \mathrm{R}^{1}=\mathrm{H} ; \mathrm{R}^{2}=4-\mathrm{F}$ & $2 a, \mathrm{R}^{3}=4-\mathrm{CH}_{3} \mathrm{C}_{6} \mathrm{H}_{4}$ & $3 \mathbf{f}$ & 94 \\
\hline 9 & $\mathbf{1 i}, \mathrm{R}^{1}=\mathrm{H} ; \mathrm{R}^{2}=4-\mathrm{CF}_{3}$ & $2 \mathrm{a}, \mathrm{R}^{3}=4-\mathrm{CH}_{3} \mathrm{C}_{6} \mathrm{H}_{4}$ & $3 \mathbf{i}$ & 96 \\
\hline 10 & $\mathbf{1 j}, \mathrm{R}^{1}=\mathrm{H} ; \mathrm{R}^{2}=4-\mathrm{CH}_{3}$ & $2 \mathrm{a}, \mathrm{R}^{3}=4-\mathrm{CH}_{3} \mathrm{C}_{6} \mathrm{H}_{4}$ & $3 \mathbf{j}$ & 70 \\
\hline 11 & $\mathbf{1} \mathbf{k}, \mathrm{R}^{1}=\mathrm{H} ; \mathrm{R}^{2}=4-t-\mathrm{Bu}$ & $2 a, \mathrm{R}^{3}=4-\mathrm{CH}_{3} \mathrm{C}_{6} \mathrm{H}_{4}$ & $3 \mathbf{k}$ & 91 \\
\hline 12 & $11, \mathrm{R}^{1}=\mathrm{H} ; \mathrm{R}^{2}=4-\mathrm{OCH}_{3}$ & $2 a, \mathrm{R}^{3}=4-\mathrm{CH}_{3} \mathrm{C}_{6} \mathrm{H}_{4}$ & 31 & 90 \\
\hline 13 & $1 \mathrm{a}, \mathrm{R}^{1}=\mathrm{H} ; \mathrm{R}^{2}=\mathrm{H}$ & $2 \mathbf{b}, \mathrm{R}^{3}=\mathrm{Ph}$ & $3 \mathbf{m}$ & 83 \\
\hline 14 & $1 \mathrm{a}, \mathrm{R}^{1}=\mathrm{H} ; \mathrm{R}^{2}=\mathrm{H}$ & $2 \mathrm{c}, \mathrm{R}^{3}=4-\mathrm{CH}_{3} \mathrm{OC}_{6} \mathrm{H}_{4}$ & $3 n$ & 89 \\
\hline
\end{tabular}

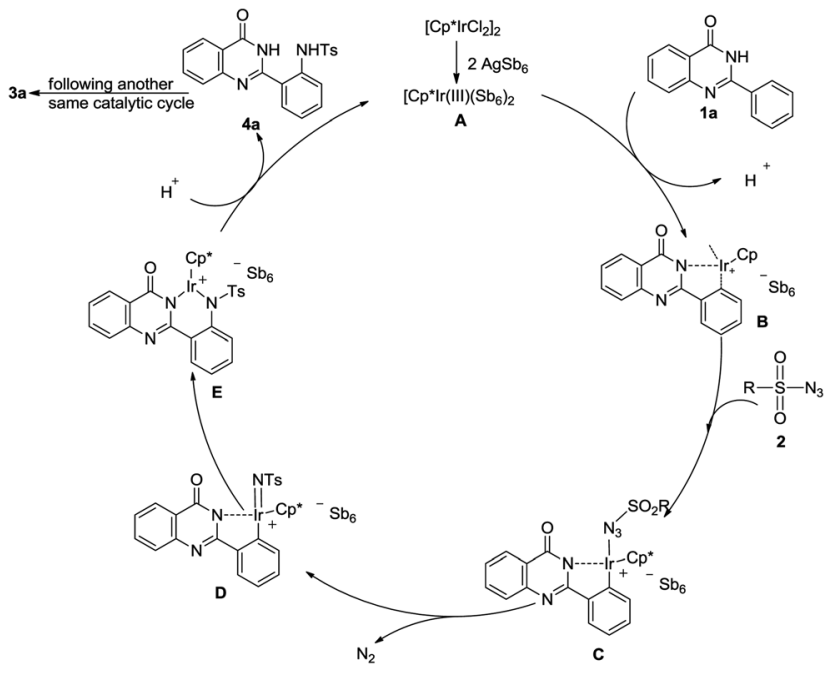

Scheme 3 The proposed reaction mechanism.

To clarify the reaction mechanism, some control experiments were carried out (Scheme 2). First, 4-methyl- $N$-(2-(4-oxo3,4-dihydroquinazolin-2-yl)phenyl)benzenesulfonamide and 3a were obtained in $43 \%$ and $22 \%$ yields when 1a $(0.3$ $\mathrm{mmol})$ was treated with $2 \mathrm{a}(0.2 \mathrm{mmol})$ under the optimized conditions (Scheme 2a). Additionally, $\mathbf{4 a}(0.2 \mathrm{mmol})$ could react with $2 \mathbf{a}(0.22 \mathrm{mmol})$ to give the expected product $3 \mathbf{a}$ in $90 \%$ yield (Scheme $2 \mathrm{~b}$ ). To confirm which $\mathrm{N}$ atom of quinazolinones (1a) was coordinating with Ir(III), NH-protected quinazolinone (5) was introduced to the reaction. No target product (6a or 7a) was obtained (Scheme 2c). These results suggested that NH of quinazolinones (1a) played as a directing group in the catalytic cycle, and compound $4 \mathbf{a}$ was the key intermediate in this reaction.

Based on the results obtained and the literatures,${ }^{15}$ a plausible reaction pathway for this $\operatorname{Ir}($ III)-catalysed amidation reaction was proposed and shown in Scheme 3. Initially, the dimeric precursor $\left[\mathrm{IrCp}^{*} \mathrm{Cl}_{2}\right]_{2}$ was converted into a cationic species $\mathbf{A}$ by the aid of silver salt. The five-membered iridacycle $\mathbf{B}$ with one vacant accessible site was formed by the coordination of the iridium atom with the nitrogen atom, and subsequently an electrophilic attack at the ortho-position carbon atom. Then, intermediate $\mathbf{C}$ was formed through interaction of azide with the cationic metal center. It was proposed that intermediate $\mathbf{D}$ from complex $\mathbf{C}$ occurred in an oxidative manner to release the $\mathrm{N}_{2}$ molecule. A new C-N bond was formed by insertion of the $\mathrm{N}-$ Ts imines species into a new iridacycle $\mathbf{E}$. The compound $\mathbf{E}$ was protodemetalated to deliver the sulfamidated product $4 \mathbf{4 a}$. Finally, the desired product 3a was generated via another same catalytic cycle from compound $\mathbf{4 a}$.

\section{Conclusions}

In summary, we have demonstrated an Ir-catalysed direct amidation of 2-arylquinazolinones with sulfonyl azides as amino sources to produce a series of ortho-diamided quinazolinones. This transformation involves two $\mathrm{C}-\mathrm{N}$ bonds formation with low catalyst loading under mild conditions and wide functional group tolerance. Moreover, this approach provided a fast-track strategy for atom/step economical syntheses of useful pharmaceutical molecules with $\mathrm{N}_{2}$ as the sole byproduct. The products obtained are important building blocks in organic synthesis and could be easily converted into various highly valuable 
molecules via diverse transformations. Further study on the application of this reaction is ongoing in our laboratory.

\section{Conflicts of interest}

There are no conflicts to declare.

\section{Acknowledgements}

This work was supported by the NSF of China (No. 21572072 and 21602064), Xiamen Southern Oceanographic Center (15PYY052SF01) and Y. F. thanks the Graduate Innovation Fund of Huaqiao University.

\section{Notes and references}

1 For selected reviews see: (a) M. P. Doyle and K. I. Goldberg, Acc. Chem. Res., 2012, 45, 777; (b) T. Bruckl, R. D. Baxter, Y. Ishihara and P. S. Baran, Acc. Chem. Res., 2012, 45, 826; (c) P. B. Arockiam, C. Bruneau and P. H. Dixneuf, Chem. Rev., 2012, 112, 5879; (d) C.-L. Sun, B.-J. Li and Z.-J. Shi, Chem. Rev., 2011, 111, 1293; (e) T. W. Lyons and M. S. Sanford, Chem. Rev., 2010, 110, 1147; $(f)$ J. Yamaguchi, A. D. Yamaguchi and K. Itami, Angew. Chem., Int. Ed., 2012, 51, 8960; (g) D. A. Colby, R. G. Bergman and J. A. Ellman, Chem. Rev., 2010, 110, 624; (h) J. Wencel-Delord, T. Drcge, F. Liu and F. Glorius, Chem. Soc. Rev., 2011, 40, 4740; (i) T. Satoh and M. Miua, Chem.-Eur. J., 2010, 16, 11212; (j) G. Y. Song, F. Wang and X. Li, Chem. Soc. Rev., 2012, 41, 3651; (k) L. Ackermann and J. Pospech, Org. Lett., 2011, 13, 4153; (l) T. Ueyama, S. Mochida, T. Fukutani, K. Hirano, T. Satoh and M. Miura, Org. Lett., 2011, 13, 706; $(m)$ H. Weissman, X. Song and D. Milstein, J. Am. Chem. Soc., 2001, 123, 337; (n) J. Wu, X. Cui, X. Mi, Y. Li and Y. Wu, Chem. Commun., 2010, 46, 6771; (o) L. Ackermann, L. Wang and A. V. Lygin, Chem. Sci., 2012, 3, 177.

2 (a) W. Yang, J. Wang, Z. Wei, Q. Zhang and X. Xu, J. Org. Chem., 2016, 81, 1675; (b) S. E. Walker, J. A. Jordan-Hore, D. G. Johnson, S. A. Macgregor and A. L. Lee, Angew. Chem., Int. Ed., 2014, 53, 13876; (c) A. Honraedt, F. Le Callonnec, E. Le Grognec, V. Fernandez and F.-X. Felpin, J. Org. Chem., 2013, 78, 4604; (d) T. Zhou, L. Li, B. Li, H. Song and B. Wang, Org. Lett., 2015, 17, 4204; (e) Y. Fujiwara, V. Domingo, I. B. Seiple, R. Gianatassio, M. D. Del Bel and P. S. Baran, J. Am. Chem. Soc., 2011, 133, 3292; $(f)$ S. Shaaban, A. Jolit, D. Petkova and N. Maulide, Chem. Commun., 2015, 51, 13902; ( $g$ ) G. A. Jardim, J. F. Bower and S. J. E. Da, Org. Lett., 2016, 18, 4454; $(h)$ B.-J. Li and Z.-J. Shi, Chem. Soc. Rev., 2012, 41, 5588; (i) N. Kuhl, N. Schroder and F. Glorius, Adv. Synth. Catal., 2014, 356, 1443; (j) J. Mo, L. Wang, Y. Liu and X. Cui, Synthesis, 2015, 47, 439.

3 (a) L. Ackermann, R. Vicente and A. R. Kapdi, Angew. Chem., Int. Ed., 2009, 48, 9792; (b) D. Alberico, M. E. Scott and M. Lautens, Chem. Rev., 2007, 107, 174; (c) T. W. Lyons and M. S. Sanford, Chem. Rev., 2010, 110, 1147; (d) R. Giri,
B.-F. Shi, K. M. Engle, N. Maugel and J.-Q. Yu, Chem. Soc. Rev., 2009, 38, 3242; (e) L. McMurray, F. O'Hara and M. J. Gaunt, Chem. Soc. Rev., 2011, 40, 1885; (f) M. A. Battiste, P. M. Pelphrey and D. L. Wright, Chem.-Eur. J., 2006, 12, 3438; (g) H. Butenschön, Angew. Chem., Int. Ed., 2008, 47, 5287; (h) K. E. O. Ylijoki and J. M. Stryker, Chem. Rev., 2013, 113, 2244; (i) M. Harmata, Chem. Commun., 2010, 46, 8886.

4 A. K. Nanda, S. Ganguli and R. Chakraborty, Molecules, 2007, $12,2413$.

5 J.-H. Chan, J.-S. Hong, L. F. Kuyper, D. P. Baccanari, S. S. Joyner, R. L. Tansik, C. M. Boytos and S. K. Rudolph, J. Med. Chem., 1995, 38, 3608.

6 H. Kikuchi, K. Yamamoto, S. Horoiwa, S. Hirai, R. Kasahara, N. Hariguchi, M. Matsumoto and Y. Oshima, J. Med. Chem., 2006, 49, 4698.

7 (a) Y. Takase, T. Saeki, N. Watanabe, H. Adachi, S. Souda and I. Saito, J. Med. Chem., 1994, 37, 2106; (b) M. Dupuy, F. Pinguet, O. Chavignon, J. M. Chezal, J. C. Teulade, J. P. Chapat and Y. Blache, Chem. Pharm. Bull., 2001, 49, 1061; (c) P. M. Chandrika, T. Yakaiah, A. R. R. Rao, B. Narsaiah, N. C. Reddy, V. Sridhar and J. V. Rao, Eur. J. Med. Chem., 2008, 43, 846.

8 M.-H. Yen, J.-R. Sheu, I.-H. Peng, Y.-M. Lee and J.-W. J. Chern, Pharmacol. Pharm., 1996, 48, 90.

9 (a) J. Kunes, J. Bazant, M. Pour, K. Waisser, M. Slosarek and J. Janota, Farmaco, 2000, 55, 725; (b) K. Waisser, J. Gregor, H. Dostal, J. Kunes, L. Kubicova, V. Klimesova and J. Kaustova, Farmaco, 2001, 56, 803.

10 A. Archana, V. K. Shrivastava, R. Chandra and A. Kumar, Indian J. Chem., Sect. B: Org. Chem. Incl. Med. Chem., 2002, 41, 2371.

11 Y. Feng, N. Tian, Y. Li, C. Jia, X. Li, L. Wang and X. Cui, Org. Lett., 2017, 19, 1658.

12 (a) J. Kim and S. Chang, Angew. Chem., Int. Ed., 2014, 53, 2203; (b) T. Kang, Y. Kim, D. Lee, Z. Wang and S. Chang, J. Am. Chem. Soc., 2014, 136, 4141; (c) H. Hwang, J. Kim, J. Jeong and S. Chang, J. Am. Chem. Soc., 2014, 136, 10770; (d) C. Pi, X. Cui and Y. Wu, J. Org. Chem., 2015, 80, 7333; (e) B. Zhu, X. Cui, C. Pi, D. Chen and Y. Wu, Adv. Synth. Catal., 2016, 358, 326; (f) Y. Park, Y. Kim and S. Chang, Chem. Rev., 2017, 117, 9247; $(g)$ D. Lee, Y. Kim and S. Chang, J. Org. Chem., 2013, 78, 11102; (h) T. Kang, H. Kim, J. G. Kim and S. Chang, Chem. Commun., 2014, 50, 12073; (i) H. Kim, G. Park, J. Park and S. Chang, ACS Catal., 2016, 6, 5922.

13 Y. Li, Y. Feng, L. Xu, L. Wang and X. Cui, Org. Lett., 2016, 18, 4924.

14 (a) Y. Li, M. Gao, L. Wang and X. Cui, Org. Biomol. Chem., 2016, 14, 8428; (b) M. Gao, Y. Li, L. Xie, R. Chauvin and X. Cui, Chem. Commun., 2016, 52, 2846; (c) M. Wei, L. Wang and X. Cui, Chin. Chem. Lett., 2015, 26, 1336; (d) L. Wang, Z. Yang, M. Yang, R. Zhang, C. Kuai and X. Cui, Org. Biomol. Chem., 2017, 15, 8302.

15 (a) J. Kim and S. Chang, Angew. Chem., Int. Ed., 2014, 53, 2203; (b) J. Kim and S. Chang, Chem.-Eur. J., 2013, 19, 7328; (c) J. Ryu, K. Shin, S. H. Park, J. Y. Kim and 
S. Chang, Angew. Chem., Int. Ed., 2012, 51, 9904; (d) T. Kang, Y. Kim, D. Lee, Z. Wang and S. Chang, J. Am. Chem. Soc., 2014, 136, 4141; (e) H. Hwang, J. Kim, J. Jeong and S. Chang, J. Am. Chem. Soc., 2014, 136, 10770; (f) C. Pi, X. Cui and Y. Wu, J. Org. Chem., 2015, 80, 7333; $(g)$ K. Shin, H. Kim and S. Chang, Acc. Chem. Res., 2015, 48, 1040; $(h)$ Y. Park, K. T. Park, J. G. Kim and S. Chang, J. Am. Chem. Soc., 2015, 137, 4534; (i) K. Shin, Y. Baek and S. Chang, Angew. Chem., Int. Ed., 2013, 52, 8031; (j) J. Y. Kim, S. H. Park, J. Ryu, S. H. Cho, S. H. Kim and S. Chang, J.
Am. Chem. Soc., 2012, 134, 9110; (k) B. Zhu, X. Cui, C. Pi, D. Chen and Y. Wu, Adv. Synth. Catal., 2016, 358, 326; $(l)$ L. Xu, L. Wang, Y. Feng, Y. Li, L. Yang and X. Cui, Org. Lett., 2017, 19, 4343; (m) Z. Qi, S. Yu and X. Li, Org. Lett., 2016, 18, 700; (n) Y. Li, Z. Qi, H. Wang, X. Yang and X. Li, Angew. Chem., Int. Ed., 2016, 128, 12056; (o) K. Shin, H. Kim and S. Chang, Acc. Chem. Res., 2015, 48, 1040; (p) H. Kim, K. Shin and S. Chang, J. Am. Chem. Soc., 2014, 136, 5904; (q) J. Ryu, J. Kwak, K. Shin, D. Lee and S. Chang, J. Am. Chem. Soc., 2013, 135, 12861. 